\title{
Diversity of Lactic Acid Bacteria (LAB) in Fermented Fish Products: A Review
}

\author{
Soibam Ngasotter ${ }^{1 *}$, David Waikhom ${ }^{1}$, Susmita Mukherjee ${ }^{2}$, \\ Manoharmayum Shaya Devi ${ }^{3}$ and Asem Sanjit Singh ${ }^{4}$
}

${ }^{1}$ College of Fisheries, Central Agricultural University (I), Lembucherra, Tripura-799210, India

${ }^{2}$ Faculty of Fishery Sciences, West Bengal University of Animal and Fishery Sciences (WBUAFS), Kolkata-700094, India

${ }^{3}$ ICAR-Central Inland Fisheries Research Institute (CIFRI), Barrackpore-700120, India

${ }^{4}$ ICAR-Central Institute of Fisheries Education (CIFE), Mumbai-400061, India

*Corresponding author

\section{A B S T R A C T}

\section{Keywords}

Lactic acid bacteria, LAB, Probiotics,

Fermented fish,

Southeast Asian countries

\section{Article Info}

Accepted: 18 April 2020 Available Online: 10 May 2020
The purpose of this review article on the diversity of Lactic acid bacteria (LAB) in fermented fish products is to empower the readers about the various diversity of lactic acid bacteria in fermented fish products, their role in fish preservation, their origin and molecular approaches for identification of Lactic acid bacteria (LAB) from fermented foods. Fermented fish products are very popular in Southeast Asian countries such as Thailand, Indonesia, Philippines, Malaysia, China, and Northeast parts of India. It is considered a delicacy and is eaten in their day to day life. LAB plays an important role in fish fermentation also it is responsible for the unique characteristics of fermented fish. Certain LAB species also display probiotic activity and have been widely used in the food industry as a result of their potential health benefits. This review provides information on LAB species associated with various fermented fish products of Southeast Asian countries.

\section{Introduction}

Lactic acid bacteria (LAB) are a group of gram-positive bacteria that are devoid of cytochromes and preferring anaerobic conditions, they are usually non-motile, non- sporulating, catalase-negative, oxidasenegative, acid-tolerant and strictly fermentative bacteria that produce lactic acid as a major or sole product of fermentative metabolism. They are either rod-shaped (bacilli) or spherical-shaped (cocci) that share 
common metabolic and physiological characteristics. LAB are nutritionally fastidious, requiring carbohydrates, amino acids, peptides, nucleic acid derivates, and vitamins. Based on their fermentative metabolism LAB are divided into two distinct groups. The homo-fermentative group that utilizes the Embden-Meyerhof-Parnas (glycolytic) pathway to transform a carbon source chiefly into lactic acid. Heterofermentative bacteria produce equimolar amounts of lactate, $\mathrm{CO}_{2}$, ethanol, or acetate from glucose exploiting the phosphoketolase pathway. The homo-fermentative group consists of Lactococcus, Pediococcus, Enterococcus, Streptococcus, etc and the heterofermentative group includes Leuconostoc, Weissella, etc. (Vasiljevik and Shah, 2008).

Lactic acid bacteria (LAB) are acid-producing (lactic acid) and are acid-tolerant which helps LAB to outcompete other bacteria in a natural fermentation thus inhibiting the growth of spoilage as well as pathogenic microorganisms (Kobayashi et al., 2004). Most fermented foods owe their origin to the fact that the processes used in their production are inhibitory to many microorganisms. As a result, fermented products generally have a longer shelf life than their original substrate and their ultimate spoilage is different (Adams and Mitchell, 2002). Lactic acid bacteria (LAB) have been shown to produce uricase (Handayani et al., 2018), reduce ochratoxin A (Luz et al., 2018), reduce acrylamide formation in bread (Nachi et al., 2018), produce exopolysaccharides (Abid et al., 2018), remove tannins (Shang et al., 2019). Some LAB strains have also been reported to increase folic acid levels in fermented milk (Purwadani et al., 2017).

LAB are amongst the most important groups of microorganisms used in the food industry. The industrial significance of the LAB is further evidenced by their generally recognized as safe (GRAS) status, because of their ubiquitous appearance in food and their contribution to the healthy and sound microbiota of animal and human mucosal surfaces. Lactic acid bacteria (LAB) include members of the genera Streptococcus, Enterococcus, Lactobacillus, Aerococcus, Carnobacterium, Leuconostoc, Lactococcus, and Pediococcus. Peripherally Oenococcus, Sporolactobacillus, Tetragenococcus, Vagococcus, and Weissella also are regarded as LAB; these belong to the order Lactobacillales.

\section{Lactic acid bacteria (LAB) and fermentation of fish}

Fish is a perishable commodity and hence fermentation of fish for increasing its shelf life is an old age practice. The fermentation of fish is mainly carried out in Asian countries. The storage life of perishable fish can be increased by acid-fermentation with added carbohydrates and salts. Both freshwater and seawater fish are preserved by this method. Rice, flour, millet, and even syrup or sugar are used as carbohydrate sources. In Southeastern countries, rice is commonly used as a carbohydrate source whereas Millet is used as the main carbohydrate source in Northeastern countries. The organic acids produced from the added carbohydrates in combination with salt control the extent of acid fermentation and keep the quality of the product (Rhee et al., 2011).

During fermentation, the production of lactic acid from $\mathrm{LAB}$ decreases the $\mathrm{pH}$ of the product thereby decreasing the number of other microbes. The typical acid-forming bacteria rapidly increase in number, becoming the predominant microbes after fermentation has started and reaches their maximum density at the end of fermentation. Also, it contributes to the unique and characteristic 
flavor of the fermented fish. LAB plays an important role in food fermentation that causes changes in taste, texture, and smell with improved preservation of the product (Hugas, 1998). Fermented fish products formed the unique acids, alcohols, phenols, and other fermented flavor substances and good taste under the action of microorganisms and enzymes of their metabolic process.

Lactic acid bacteria (LAB) also play an important role as probiotics in many Asian fermented foods. Koreans who travel overseas for several days without fermented foods often experience uncomfortable stomach symptoms and poor digestion. More research is needed to identify the lactic acid bacteria in Asian fermented foods and their physiological functions in the human diet (Rhee et al., 2011)

Origin of Lactic acid bacteria (LAB) in traditional fermented fish products

Fermentation as a method of food preservation is one of the most old age practice in the world. Fermented fish products are reported to be dominated by mostly lactic acid bacteria by many researchers. Lactic acid bacteria (LAB) are the most commonly used microorganisms in fermentation technique although most of the fermentation of traditional products are done using spontaneous fermentation at an anaerobic condition in which microorganism already present in the raw materials becomes the normal flora at the time of fermentation. Studies have demonstrated that lactic acid bacteria are part of the normal intestinal microbiota in fish. Presence of Lactic acid bacteria in the raw materials used for fermentation such as rice, garlic, banana leaves including fish has also been reported (Paludan-Müller et al., 1999). Some information on the presence of Lactobacillus spp. in the digestive tract of salmonids have been already reviewed (Ring $\varnothing$ et al., 1995). There are reports that LAB is a part of native microbiota of aquatic animals (Ringo, 2004). Itoi et al., (2008) reported that halotolerant strains of Lactococcus lactis isolated from the intestinal tract of the pufferfish Takifuguniphobles caught in Shimoda, Shizuoka, Japan. Nair and Surendran (2005) isolated LAB from various samples of fresh and frozen fish and prawn. Among the isolates, Lactobacillus plantarum was the dominant species. Thus, in traditional methods the fermentation is initiated with spontaneous growth of fortuitous microorganisms during the production. Some studies also suggested that fermented food characteristics varied with raw material and additional material used that caused the microbial diversity in the food (Kopermsub et al., 2006). Although the use of starter cultures would be an appropriate approach for the control and optimization of the fermentation process.

\section{Role of Lactic acid bacteria (LAB) in food preservation}

Presence of Lactic acid bacteria in fermented food has been the major reason for the preservation of food. The inhibitory effect towards spoilage and pathogenic bacteria mainly comes from organic acid. Lactic acid produced by LAB is a useful compound for food preservation because it maintains the acidic conditions of the fermented products, and is lethal to bacteria that cause food spoilage and food poisoning (Kobayashi et al., 2004). During the process of fermentation, LAB could utilize carbohydrate substrates available in the fermenting matrix and produce organic acids, especially lactic acid that not only contributes to the taste, aroma, and texture of the product but also lowers the product's $\mathrm{pH}$ that is one of the key factors to ensure the quality and safety of the product. Besides that, strains of certain LAB 
species display probiotic activity and have been widely used in food industry as a result of their potential health benefits (Giraffa, 2004).

\section{Molecular approaches for identification of Lactic acid bacteria (LAB) from fermented foods}

The correct species identification of LAB is of paramount importance from the technological, ecological, and safety point of view (Temmerman et al., 2004).

Recently, knowledge of the taxonomic diversity and heterogeneity of LAB related to fish fermentation requires cultivable approaches combined with various DNAbased techniques (Vignolo et al., 2012). As a powerful tool, $16 \mathrm{~S}$ ribosomal RNA gene (16S rDNA) sequence analysis has become a major criterion for the phylogenetic identification of bacteria and is increasingly being adopted for rapid analysis of the $\mathrm{LAB}$ communities involved in many kinds of fermented food products (Kopermsub and Yunchalard, 2010; Koyanagi et al., 2011). Among various DNA typing methods, amplified ribosomal DNA restriction analysis (ARDRA) of 16S rDNA has been considered as the prototype of a DNA fingerprinting method mostly used to identify isolates present in many fermented foods (Rodas et al., 2003; Santos et al., 2005; Solieri et al., 2012).

Diversity of lactic acid bacteria (LAB) in fermented fish products around the globe

Many studies have been done on the isolation and characterization of Lactic acid bacteria (LAB) from fermented fish products. Most of the studies have been carried out in Southeast Asian countries like Thailand, Indonesia, China, Malaysia, etc. where fermented fish products are considered a delicacy and are eaten in their day to day life.

\section{Thailand}

Some important fermented fish products of Thailand are Plaa-som, Som-fak, pla-ra, plachom, kung-chom, and hoi-dorng.

\section{Plaa-som}

Plaa-som is a traditional fermented fish product widely consumed in the south of Thailand. It is made from fish, sugar, salt, and roasted rice and is fermented with natural microbial flora. Either the whole fish or fish fillets are fermented with either cooked rice or steamed sticky rice, garlic, and salt until a final acceptable sour-tasting product is obtained. After fermentation, the fish is cooked by either deep frying or roasting and consumed. As a traditional fermented food product, its recipes vary by region throughout the Kingdom of Thailand, depending upon local consumer preferences and ingredient availability (Valyasevi and Rolle, 2002). The production process traditionally relies on a spontaneous fermentation initiated by natural fortuitous microorganisms, mainly lactic acid bacteria (LAB), that are found in the ingredients, on the processing utensils, and in the local atmosphere as natural starters (Khieokhachee et al., 1997; Valyasevi and Rolle, 2002; Visessanguan et al., 2004).

Hwanhlem et al., (2011) isolated Lactic acid bacteria (LAB) from Plasom at various fermentation periods using MRS agar medium containing $\quad 0.3 \% \quad(\mathrm{w} / \mathrm{v}) \quad \mathrm{CaCO}_{3}$ as a preliminary screening medium,138 isolates which exhibited a clear zone and growth on MRS agar supplemented with $\mathrm{CaCO}_{3}$ were isolated. However, only 133 isolates were identified as LAB. Calcium carbonate is used as an indicator of acid-producing strains since it gets dissolved when it interacts with acidforming a clear zone (Onda et al., 2002). Of these 133 isolates, 25 isolates were cocci, 75 isolates were short rods and 33 isolates were 
rods. The strain which showed the best lactic acid production and $\mathrm{pH}$ reduction ability were identified upto species level by $16 \mathrm{~S}$ rDNA analysis and were identified as Streptococcus salivarius and Enterococcus faecalis based on their morphological properties, biochemical tests, and 16S rDNA analysis. These strains were gram-positive, non-spore forming cocci, catalase-negative, and formed off-white colonies.

Kopermsub and Yunchalard (2010) studied the distribution and succession of predominant LAB species during plaa-som fermentation. The isolates were screened and grouped by amplified ribosomal DNA restriction analysis (ARDRA), followed by $16 \mathrm{~S}$ rDNA sequencing. The predominant LAB species were Lactococcus garvieae, Weissellacibaria, Pediococcus pentosaceus, Streptococcus bovis, Lactobacillus plantarum, and Lactobacillus fermentum. Early stages of the process were dominated by the presence of Lactococcus garvieae, Streptococcus bovis, and Weissellacibaria. At 48 hours into fermentation, Weissellacibaria, Pediococcus pentosaceus, and Lactobacillus plantarum were prevalent, and gave way to a dominance of Lactobacillus plantarum that completed the fermentation.

\section{Som-fak}

Som-fak is a Thai product composed of minced fish fillet, salt (2-5\%), ground boiled rice $(2-12 \%)$, and minced garlic $(4 \%)$. The mixture is tightly packed in banana leaves or plastic bags and left to ferment for two to five days at $30^{\circ} \mathrm{C}$ (Saisithi et al., 1986). Som-fak can be served raw or cooked either as a main course with vegetables or as a snack.

Lactic acid bacteria (LAB) were isolated and characterized from a Thai low-salt fermented fish (SomFak) product (Paludan-Müller et al., 1999). One-hundred and eighty-five LAB were isolated from raw materials and during fermentation of som-fak, isolates were identified upto species level by phenotypic characterization. At the start of fermentation, Leuconostoc spp., Lactobacillus brevis and Lactococcus lactis were dominant, followed by more acid-tolerant species of Lactobacillus curvatus, Lactobacillus casei, Lactobacillus pentosus and Lactobacillus plantarum. At the end of fermentation Lactobacillus plantarum was the most dominant microflora.

Pediococcus sp. and Lactobacillus sp. have been identified as the dominating LAB genera in commercial samples of som-fak and those prepared in the laboratory (Tanasupawat et al., 1993; Saisithi et al., 1986).

\section{Hoi-dorng}

Hoi-dorng is a high salt fermented product of Thailand. Hoi-dorng is produced from sea mussel meat washed in brine $(10 \% \mathrm{NaCl})$ and water. After drainage, sea salt is added (ratio: 7:1 by weight) and mixed well. The product matures for 4-5 days and is packed in sealed glass jars, it has a shelf-life of 3-6 months (Phithakpol et al., 1995).

Østergaard et al., (1998) isolated and screened for lactic acid bacteria (LAB) capable of inhibiting Listeria sp. (Listeria innocua) from three Thai fermented fish products (Hoi-dorng, Plaa-som, and Somfak). The strains isolated were identified to be Lactobacillus sp., Lactobacillus plantarum, Carnobacterium piscicola, and Lactococcus lactis. Lactobacillus species were the most predominant, accounting for 29 of the 44 strains.

\section{Pla-ra, Pla-chom, Kung-chom, and Hoi- dorng}

Traditional fermented fish with salt-nampla, budu, tai-pla, pla-ra, pla-chom, kungchom, and hoi-dorng - are found in different parts of Thailand (Tanasupawat and 
Komagata, 1995). Pla-ra is a highly salted fermented fish, whereas pla-chom, kungchom, and hoi-dong, are the lowly salted products. Lactic acid bacteria (LAB) were isolated and characterized from these four products (Tanasupawat et al., 1998). The isolated bacteria were identified by phenotypic and chemotaxonomic characteristics, including fluorometric DNADNA hybridization. Lactobacillus farciminis, Leuconostoc sp., and other Lactobacillus sp. were found in Pla-ra, Lactobacillus pentosus, L. farciminis and other Lactobacillus sp. in Pla-chom, L. pentosus, L. plantarum, and $L$. farciminis in Kung-chom and L. farciminis in Hoi-dorng.

\section{Indonesia}

\section{Bekasam}

Bekasam is a fermented fish product of Indonesia with a sour taste and it is a popular food in Central Java, South Sumatra, and South Kalimantan. Bekasam production involves a spontaneous fermentation process of freshwater fish, supplemented by salt, and rice or fermented cassava (Murtini et al., 1997). In som-fak, the rapid growth of LAB causes $\mathrm{pH}$ to decrease below 4.5 in two days is essential to prevent spoilage and to ensure the safety of the product (Østergaard et al., 1998).

Choesri et al., (2013) isolated and characterized LAB isolates from bekasam. Seventy-four isolates were isolated out of which 62 isolates $(84 \%)$ belonged to LAB based on morphological and biochemical characteristics. Although the isolates were not identified upto species level.

\section{Rusip}

Rusip is one of the typical lactic acid fish fermented food originating from Bangka Belitung, Indonesia. It is a traditional fermented fish products known from Bangka Belitung and found in Lampung and West Kalimantan. Small fish such as anchovy or Bilis fish are used as raw materials in the manufacture of rusip. Fermentation of rusip is usually a spontaneous process involving lactic acid bacteria (LAB) with palm sugar as a source of carbohydrates. Genus of lactic acid bacteria involved in a food fermentation may vary depending on region, type of substrate, and or fermentation stages.

The LAB species encountered in the final end product of rusip with the addition of salt and roasted rice are Streptococcus and Lactobacillus, whereas in rusip with the addition of salt and brown sugar were Leuconostoc and Streptococcus. These lactic acid bacteria were found in the final product of rusip originating from manufacturers in Bangka (Dessi, 1999). Kusmarwati et al., (2014) found Pediococcus as bacteriocin producing lactic acid bacteria from commercial rusip in Bangka and West Kalimantan. Yuliana et al., (2018) isolated and identified lactic acid bacteria from rusip at different fermentation stages for upto 15 days. The results showed that the lactic acid bacteria contributing during rusip fermentation was Leuconostoc, Streptococcus, and Lactococcus. Based on the fermentation periods, the presence of these bacteria was varying. The genus Streptococcus was more common in early fermentation, whereas the genus of Lactococcus was more common in mid-fermentation and at the end of fermentation, the most dominant was Leuconostoc.

\section{Chao}

Chao is a traditional fermented food from Pangkajene and Kepulauan Regency, South Sulawesi, Indonesia. This product is fermented from fish and white rice. Tembang fish (Sardinella gibbosa) is one type of fish that is often processed. 
Matti et al., (2019) isolated and identified proteolytic lactic acid bacteria (LAB) from chao. Characterization and selection of isolate were performed based on morphological and biochemical characteristics, proteolytic activities, phenotype, and repetitive sequencepolymerase chain reaction (Rep-PCR) amplification. The similarity of isolates was compared based on the 16S rRNA gene sequence and phylogenetic analysis. Sixty isolates of LAB were isolated from chao. Fifteen isolates were halotolerant proteolytic LAB. Further identification confirmed the strains to be Lactobacillus plantarum, Lactobacillus curvatus, Pediococcus pentosaceus, and Pediococcus acidilactici.

\section{China}

\section{Chouguiyu (Stinky Mandarinfish)}

Chouguiyu (stinky mandarinfish), is a traditional fermented fish product of China, famous for its uniquely strong odour and desirable taste. It is made from mandarinfish by spontaneous fermentation under an anaerobic condition with low-salt concentration. It is found in many areas in China, especially the Lakelands where the mandarinfish are cultivated. Among them, the most famous one is Huangshan Chouguiyu that is produced in the Huangshan Mountain area in Anhui province and the product is a note for its uniquely firm but tender texture and special strong odour.

Dai et al., (2013) studied the diversity of predominant species of LAB involved in the traditional fermented fish product, Chouguiyu at different stages of fermentation. Sixty-one isolates of lactic acid bacteria (LAB) were isolated using MRS agar media and characterized from various fermentation periods based on a combination of phenotypic and genotypic approaches including amplified ribosomal DNA restriction analysis
(ARDRA) and 16S rRNA partial gene sequencing analysis. LAB isolates from the Chouguiyu exhibited a big diversity with 8 species belonging to 6 different genera. Lactobacillus sakei was the predominant species $(63 \%)$ during the fermentation. The other lactic acid bacteria (LAB) species identified were Lactococcus garvieae, Lactococcus raffinolactis, Lactococcus lactis, Vagococcus sp., Enterococcus hermanniensis, Macrococcus caseolyticus and Streptococcus parauberis, the latter was recovered from the different fermentation periods, especially at the initial stages of the fermentation.

\section{Traditional Fermented Sea-fish (Trachinotus ovatus, Tanichthys albonubes, and Ilishae longata)}

Zhu et al., (2016) isolated and characterized LAB from three kinds of traditional fermented fish (Trachinotus ovatus, Tanichthys albonubes, and Ilishae longata). Three strains of LAB were identified from the three kinds of fermented fish, Leuconostoc citreum, Lactococcus lactis, and Lactobacillus pentosus. All three strains were possessed a strong antibacterial activity and met the standards of the starter cultures.

\section{Philippines}

\section{Burong Bangus}

Burong Bangus is a traditional fermented fish and rice product of the Philippines in which milkfish, "Chanos chanos" or "bangus", is used.

Olympia et al., (1992) analyzed the microflora of "burong bangus" for lactic acid bacteria (LAB) during its different stages of fermentation. The results showed the succession of lactic acid bacteria during fermentation. Streptococcus initiated the fermentation process and was persistent up to 
the latter part of fermentation, this was followed by Pediococcus but comprised only a small percentage of the microflora, and then Lactobacillus and Leuconostoc appeared and were generally present up to the end of the fermentation, with Lactobacillus predominating among the microflora in the final days.

\section{Burong isda}

"Burong isda" is a traditional fermented fishery product in the Philippines which is popular in the Central Luzon region, most notably in the province of Pampanga. "Buro" means 'fermented' and "isda" means 'fish'. There are several types of "burong isda" available, the names of which are derived from the type of fish used. It is made from cooked rice and raw filleted fish fermented with salt and angkak (red yeast rice) for around a week.

Olympia et al., (1995) isolated and characterized starch-hydrolyzing Lactic Acid Bacteria (LAB) from "Burong Isda" using conventional taxonomic and DNA-DNA reassociation method. Nine strains of lactic acid bacteria that hydrolyzed starch were isolated and it was found that all the isolates belong to Lactobacillus plantarum.

\section{Malaysia}

\section{Budu}

Budu is a traditional fermented seafood product of Malaysia. It is prepared from anchovy fish and salt, then letting the combination of the mixture to ferment for up to 200 days. Tamarind and palm sugar are often added to the mix.

Liasi et al., (2009) isolated lactic acid bacteria (LAB) from the fermented food product, Budu, and their antimicrobial activity, and antibiotic susceptibility of the isolates were determined. The isolates were identified as genus lactobacillus (Lactobacillus casei, Lactobacillus plantarum, and Lactobacillus paracasei), and the most dominant species was Lactobacillus paracasei.

\section{Pekasam}

Pekasam is a Malaysian fermented fish product usually made from freshwater fish with ground roasted uncooked rice (Ezzat et al., 2015). Pekasam is most widely consumed in Peninsular Malaysia and used as an additive to improve the taste of foods.

Muryany et al., (2017) isolated and characterized Lactic Acid Bacteria (LAB) from Pekasam using $16 \mathrm{~S}$ rRNA gene sequence analysis, the isolates were identified as Lactobacillus plantarum and Lactobacillus pentosus. The isolates also exhibited the potential probiotic properties to be developed as biotherapeutic agents.

\section{India}

\section{Ngari, Hentak, and Tungtap}

Ngari, tungtap and hentak are traditional fermented fish products of North-East India. Ngari is a fermented fish product of Manipur in North-East India prepared from the fish (Puntius sophore). The fish is rubbed with salt, dried in the sun for 3-4 days, pressed tightly in an earthen pot, sealed airtight and then stored at room temperature for 4-6 months (Thapa, 2002). Ngari is eaten as a side-dish withcooked rice. Hentak is a balllike thick paste prepared by fermentation of a mixture of sun-dried fish (Esomus danricus) powder and petioles of aroid plants (Alocasia macrorhiza) in Manipur (Thapa, 2002). Dry fish is crushed to powder, an equal amount of petioles of aroid plants is mixed and a balllike thick paste is made. The mixture is kept in an earthen pot and is fermented for 7-9 days. Hentak is consumed as curry by the 
people of Manipur or as a condiment with boiled rice. Sometimes, it is given to mothers in confinement and patients in convalescence (Sarojnalini and Singh, 1988). Tungtap is a popular fermented fish product, commonly consumed by the Khasi and Jaintia tribes of Meghalaya in North-East state of India (Thapa, 2002). Dry fish (Puntius spp. and Danio spp.) is mixed with salt, kept in an earthen pot and fermented for 2-6 months. It is consumed as a pickle and a taste enhancer.

Thapa et al., (2004) studied the composition of microorganisms, mainly the lactic acid bacteria of ngari, hentak, and tungtap. Lactic acid bacteria were pre-dominant in all the three products. Theisolates were identified as Enterococcus faecium, Lactococcus lactis, Lactococcus plantarum, Lactobacillus fructosus, Lactobacillus amylophilus, Lactobacillus coryniformis subsp. Torquens and Lactobacillus plantarum. These LAB species showed high degree of hydrophobicity indicating the potential of adhesion to gut epithelial cells of human intestine, advocating their 'probiotic' character.

\section{References}

Abid, Y., Casillo, A., Gharsallah, H., Joulak, I., Lanzetta, R., Corsaro, M.M., Attia, H. and Azabou, S., 2018. Production and structural characterization of exopolysaccharides from newly isolated probiotic lactic acid bacteria. International journal of biological macromolecules, 108, 719-728.

Adams, M. and Mitchell, R., 2002. Fermentation and pathogen control: a risk assessment approach. International Journal of Food Microbiology, 79(1-2): $75-83$.

Choesri, D., Rusmana, I., Suwanto, A. and Mubarik, N.R., 2013. Characterization of lactic acid bacteria isolated from Indonesian fermented fish (bekasam) and their antimicrobial activity against pathogenic bacteria. Emirates Journal of Food and Agriculture, 25, 489-494.

Dai, Z., Li, Y., Wu, J. and Zhao, Q., 2013. Diversity of lactic acid bacteria during fermentation of a traditional Chinese fish product, Chouguiyu (stinky mandarinfish). Journal of food science, 78(11): M1778-M1783.

Dessi. 1999. SifatKimiawi dan CiriciriBakteri Pada Rusip Yang Dibuat Dengan Berbagai Sumber Karbon. Skripsi. Universitas Sriwijaya. Indralaya

Ezzat, M.A., Zare, D., Karim, R. and Ghazali, H.M., 2015. Trans-and cis-urocanic acid, biogenic amine and amino acid contents in ikanpekasam (fermented fish) produced from Javanese carp (Puntius gonionotus) and black tilapia (Oreochromis mossambicus). Food chemistry, 172, 893-899.

Giraffa, G., 2004. Studying the dynamics of microbial populations during food fermentation. FEMS Microbiology Reviews, 28(2): 251-260.

Handayani, I., Utami, T., Hidayat, C. and Rahayu, E.S., 2018. Screening of lactic acid bacteria producing uricase and stability assessment in simulated gastrointestinal conditions. International Food Research Journal, 25(4): 1661-1667

Hugas, M., 1998. Bacteriocinogenic lactic acid bacteria for the biopreservation of meat and meat products. Meat Science, 49, S139-S150.

Hwanhlem, N., Buradaleng, S., Wattanachant, S., Benjakul, S., Tani, A. and Maneerat, S., 2011. Isolation and screening of lactic acid bacteria from Thai traditional fermented fish (Plasom) and production of Plasom from selected strains. Food Control, 22(3-4): 401-407.

Itoi, S., Abe, T., Washio, S., Ikuno, E., Kanomata, Y. and Sugita, H., 2008. 
Isolation of halotolerant Lactococcus lactis subsp. lactis from intestinal tract of coastal fish. International journal of food microbiology, 121(1): 116-121.

Khieokhachee, T., Praphailong, W., Chowvalitnitithum, C., Kunawasen, S., Kumphati, S., Chavasith, V., Bhumiratana, S. and Valyasevi, R., 1997, November. Microbial interaction in the fermentation of Thai pork sausage. In Proceedings of the 6th ASEAN food conference, pp. 312-318.

Kobayashi, T., Kajiwara, M., Wahyuni, M., Hamada- Sato, N., Imada, C. and Watanabe, E., 2004. Effect of culture conditions on lactic acid production of Tetragenococcus species. Journal of applied microbiology, 96(6): 12151221.

Kopermsub, P. and Yunchalard, S., 2010. Identification of lactic acid bacteria associated with the production of plaasom, a traditional fermented fish product of Thailand. International journal of food microbiology, 138(3): 200-204.

Kopermsub, P., Vichitphan, S. and Yunchalard, S., 2006. Lactic acid bacteria isolated from Plaa-som, a Thai fermented fish product. Thailand Journal Biotechnology, 7(1): 32-39.

Koyanagi, T., Kiyohara, M., Matsui, H., Yamamoto, K., Kondo, T., Katayama, T. and Kumagai, H., 2011. Pyrosequencing survey of the microbial diversity of 'narezushi', an archetype of modern Japanese sushi. Letters in applied microbiology, 53(6): 635-640.

Kusmarwati, A., Arief, F.R. and Haryati, S., 2014. Exploration of Bacteriocin from lactic acid bacteria origin from Bangkanese and Kalimantaneserusip. JPB Perikanan, 9(1): 29-40.

Liasi, S.A., Azmi, T.I., Hassan, M.D., Shuhaimi, M., Rosfarizan, M. and Ariff, A.B., 2009. Antimicrobial activity and antibiotic sensitivity of three isolates of lactic acid bacteria from fermented fish product, Budu. Malaysian Journal of Microbiology, 5(1): 33-37.

Luz, C., Ferrer, J., Mañes, J. and Meca, G., 2018. Toxicity reduction of ochratoxin A by lactic acid bacteria. Food and chemical toxicology, 112, 60-66.

Matti, A., Utami, T., Hidayat, C. and S. Rahayu, E., 2019. Isolation, Screening, and Identification of Proteolytic Lactic Acid Bacteria from Indigenous Chao Product. Journal of Aquatic Food Product Technology, 28(7): 781-793.

Murtini, J.T., Yuliana, E. and Nasran, S., 1997. Effects of addition of lactic acid bacteria starter in the processing of spotted gouramy (Trichogaster trichopterus) bekasam in its quality and shelflife. Jurnal Penelitian Perikanan Indonesia (Indonesia), 3(2): 71-82.

Muryany, I.M., Salwany, I.M., Ghazali, A.R., Hing, H.L. and Fadilah, N.R., 2017. Identification and characterization of the Lactic Acid Bacteria isolated from Malaysian fermented fish (Pekasam). International Food Research Journal, 24(2): 868-875.

Nachi, I., Fhoula, I., Smida, I., Taher, I.B., Chouaibi, M., Jaunbergs, J., Bartkevics, V. and Hassouna, M., 2018. Assessment of lactic acid bacteria application for the reduction of acrylamide formation in bread. LWT- Food Science and Technology, 92, 435-441.

Nair, P.S. and Surendran, P.K., 2005. Biochemical characterization of lactic acid bacteria isolated from fish and prawn, 4, 48-52.

Olympia, M., Fukuda, H., Ono, H., Kaneko, Y. and Takano, M., 1995. Characterization of starch-hydrolyzing lactic acid bacteria isolated from a fermented fish and rice food, "BurongIsda", and its amylolytic enzyme. Journal of Fermentation and 
Bioengineering, 80(2): 124-130.

Olympia, M., Ono, H., Shinmyo, A. and

Takano, M., 1992. Lactic acid bacteria in fermented fishery product, "burongbangus". Journal of fermentation and bioengineering, 73(3): 193-197.

Onda, T., Yanagida, F., Uchimura, T., Tsuji, M., Ogino, S., Shinohara, T. and Yokotsuka, K., 2002. Widespread distribution of the bacteriocin- producing lactic acid cocci in Miso- paste products. Journal of applied microbiology, 92(4): 695-705.

Østergaard, A., Embarek, P.K.B., WedellNeergaard, C., Huss, H.H. and Gram, L., 1998. Characterization of antilisterial lactic acid bacteria isolated from Thai fermented fish products. Food Microbiology, 15(2): 223-233.

Paludan-Müller, C., Huss, H.H. and Gram, L., 1999. Characterization of lactic acid bacteria isolated from a Thai low-salt fermented fish product and the role of garlic as substrate for fermentation. International Journal of Food Microbiology, 46(3): 219-229.

Phithakpol, B., Varanyanond, W., Reungmaneepaitoon, S. and Wood, H., 1995. The traditional fermented foods of Thailand. 1995. Institute of Food Research and Development, Kasetsart University, Bangkok, Thailand.

Purwandhani, S.N., Utami, T., Millati, R. and Rahayu, E.S., 2017. Potensi Lactobacillus plantarum yang Diisolasidari Dadihdalam Meningkatkan Kadar Folat Susu Fermentasi. Agritech, 37(4): 395-401.

Rhee, S.J., Lee, J.E. and Lee, C.H., 2011, December. Importance of lactic acid bacteria in Asian fermented foods. Microbial Cell Factories, 10(1): 14752859

Ring $\varnothing$, E. and Gatesoupe, F.J., 1998. Lactic acid bacteria in fish: a review.
Aquaculture, 160(3-4): 177-203.

Ringo, E.I.N.A.R., 2004. Lactic acid bacteria in fish and fish farming. FOOD SCIENCE AND TECHNOLOGY-NEW YORK-MARCEL DEKKER, 139, 581610.

Rodas, A.M., Ferrer, S. and Pardo, I., 2003. 16S-ARDRA, a tool for identification of lactic acid bacteria isolated from grape must and wine. Systematic and Applied Microbiology, 26(3): 412-422.

Saisithi, P., Wongkhalaung, C., Boonyaratanakornkit, M., Yongmanitchai, P., Chimanage, P. and Maleehuan, S., 1986. Improvement of a Thai traditional fermented fish product: som-fug.

Santos, E.M., Jaime, I., Rovira, J., Lyhs, U., Korkeala, H. and Björkroth, J., 2005. Characterization and identification of lactic acid bacteria in "morcilla de Burgos". International journal of food microbiology, 97(3): 285-296.

Sarojnalini, C. and Vishwanath Singh, W., 1988. Composition and digestibility of fermented fish foods of Manipur. Journal of food science and technology (Mysore), 25(6): 349-351.

Shang, Y.F., Cao, H., Ma, Y.L., Zhang, C., Ma, F., Wang, C.X., Ni, X.L., Lee, W.J. and Wei, Z.J., 2019. Effect of lactic acid bacteria fermentation on tannins removal in Xuan Mugua fruits. Food chemistry, 274, 118-122.

Solieri, L., Bianchi, A. and Giudici, P., 2012. Inventory of non starter lactic acid bacteria from ripened Parmigiano Reggiano cheese as assessed by a culture dependent multiphasic approach. Systematic and applied microbiology, 35(4): 270-277.

Tanasupawat, S. and Komagata, K., 1995. Lactic acid bacteria in fermented foods in Thailand. World Journal of Microbiology and Biotechnology, 11(3): 253-256. 
Tanasupawat, S., Okada, S. and Komagata, K., 1998. Lactic acid bacteria found in fermented fish in Thailand. The Journal of general and applied microbiology, 44(3): 193-200.

Tanasupawat, S., Okada, S., Suzuki, K., Kozaki, M. and Komagata, K., 1993. Lactic acid bacteria, particularly heterofermentative lactobacilli, found in fermented foods in Thailand. Bulletin of the Japan Federation for Culture Collections, 9, 65-78.

Temmerman, R., Huys, G. and Swings, J., 2004. Identification of lactic acid bacteria: culture-dependent and cultureindependent methods. Trends in Food Science \& Technology, 15(7-8): 348359.

Thapa, N., 2002. Studies on microbial diversity associated with some fish products of the Eastern Himalayas.

Thapa, N., Pal, J. and Tamang, J.P., 2004. Microbial diversity in ngari, hentak and tungtap, fermented fish products of North-East India. World Journal of Microbiology and Biotechnology, 20(6): 599-607.

Valyasevi, R. and Rolle, R.S., 2002. An overview of small-scale food fermentation technologies in developing countries with special reference to Thailand: scope for their improvement.
International Journal of Food Microbiology, 75(3): 231-239.

Vasiljevic, T. and Shah, N.P., 2008. Probiotics-from Metchnikoff to bioactives. International Dairy Journal, 18(7): 714-728.

Vignolo, G., Saavedra, L., Sesma, F. and Raya, R., 2012. 22 Food Bioprotection: Lactic Acid Bacteria as Natural Preservatives. Progress in food preservation, pp. 453-483

Visessanguan, W., Benjakul, S., Riebroy, S. and Thepkasikul, P., 2004. Changes in composition and functional properties of proteins and their contributions to Nham characteristics. Meat science, 66(3): 579-588.

Yuliana, N., Koesoemawardani, D. and Susilawati, S., 2018. Lactic acid bacteria during fish fermentation (rusip). MOJ Food Processing and Technology, 6(2): 211-216.

Zhu, W.J., Zhang, X.M., Ren, W.B., Sun, L.J., Wang, Y.L. and Liu, Y., 2016. Isolation, Identification and Application of Lactic Acid Bacteria from Chinese Traditional Fermented Sea-fish. In Medicine and Biopharmaceutical: Proceedings of the 2015 International Conference, pp. 1506-1514.

\section{How to cite this article:}

Soibam Ngasotter, David Waikhom, Susmita Mukherjee, Manoharmayum Shaya Devi and Asem Sanjit Singh. 2020. Diversity of Lactic Acid Bacteria (LAB) in Fermented Fish Products: A Review. Int.J.Curr.Microbiol.App.Sci. 9(05): 2238-2249. doi: https://doi.org/10.20546/ijcmas.2020.905.255 